Egyptian Journal of Aquatic Biology \& Fisheries

Zoology Department, Faculty of Science,

Ain Shams University, Cairo, Egypt.

ISSN $1110-6131$

Vol. 23(1): $13-26$ (2019)

www.ejabf.journals.ekb.eg

\title{
Basic Parameters for Assessment and Management of the Short-Finned Squid Illex coindetii (Verany, 1839) (Cephalopoda, Ommastrephidae) from the deep water off the Egyptian Mediterranean Sea.
}

\author{
Amal M. Amin* and Manal M. Sabrah \\ National Institute of Oceanography and Fisheries, Suez, Egypt \\ *Corresponding author: aminamal30@yahoo.com
}

\begin{abstract}
ARTICLE INFO
Article History:

Received: Dec. 25, 2018

Accepted: Jan. 22, 2019

Online: Jan. 30, 2019

Keywords

Mediterranean Sea

Illex coindetii

Short-Finned Squid

Growth parameters

Mortality

Spawning period
\end{abstract}

\begin{abstract}
This research is the first study of Illex coindetii from the deep sea fishing ground adopted in the Egyptian Mediterranean Sea. That assist to prevent stock reduction by estimation of growth parameters, mortality, and size at maturity which taken as a reference point of minimum legal size to prevent stock depletion. Specimens of Illex coindetii were collected from bottom trawl vessels at 250:850 m depths from the Egyptian Mediterranean Sea. A total of 370 Illex coindetii individuals 189 males and 157 females and 24 unidentified sexes were carried out seasonally in 2016. The length-weight relationship showed negative allometry for females and sexes combined "b" 2.01, 2.64 and positive allometric growth for males " $b " 3.16$. There has been a difference between the sexes with concern length-weight relationships with males being smaller and lighter than females. Age was determined using length frequency analysis. The asymptotic length $\left(\mathrm{L}_{\infty}\right)$, the growth rate $(\mathrm{K})$ and $\left(\mathrm{t}_{0}\right)$ were estimated as $21 \mathrm{~cm}, 0.570$ year $^{-1}$ and -0.341 years for males, $31.5 \mathrm{~cm}, 0.22$ year $^{-1}$ and -0.755 year for females and $31.5 \mathrm{~cm}, 0.28$ year $^{-1}$ and 0.587 year for sexes combined respectively. The annual total mortality $(\mathrm{Z})$, natural mortality $(\mathrm{M})$ and fishing mortality $(\mathrm{F})$ were estimated at $2.94,1.05$ and 1.89/year for males while those of females were 2.76, 0.746 and 2.02 and $2.79,0.74,2.05 /$ year for the sexes combined respectively. $\mathrm{ML}_{50}$ was estimated as, $14.35 \mathrm{~cm}$ for females and $11.51 \mathrm{~cm}$ for males. Two peaks in GSI were attained of mature females, one in spring and the other in autumn. The result of the exploitation rate of the sexes combined (0.73) indicated overexploitation which was higher in females $(0.73)$ than males $(0.64)$.
\end{abstract}

\section{INTRODUCTION}

Cephalopoda is a group of mollusks that include squid, nautilus, cuttlefish, and octopus the importance of cephalopods as a world-wide fisheries resource continues to increase, they are good protein and lipid source however, their short life cycles and variable growth rates make stocks unstable and vulnerable (Pierce and Guerra, 1994). Squids represent the largest fraction (more than70\%) of world cephalopod capture production. Since 1996, squid's landings have constantly exceeded 3 million tons and peaked in 2007 with about 4.3 million tons and about 4 million tons in 2012, (FAO, 2014). In the Egyptian Mediterranean waters, the cephalopods constitute $9.8 \%$ of the total fish catch of which $61 \%$ are cuttlefishes, $3.5 \%$ octopuses, and $0.21 \%$ squids. (Riad, 1993). Illex genus contains four species: Illex argentinus, Illex illecebrosus, 
Illex oxygonius and Illex coindetii. In the present work will throw light on the state of the stock of Illex coindetii from the deep water off the Egyptian Mediterranean Sea. It is an Ommastrephid inhabiting the water column on the continental slope and shelf lives a wide range of depths from 20 to $1100 \mathrm{~m}$, being common between 100 and 400m (Guerra, 1992). It is widely distributed in the Mediterranean Sea generally caught by bottom trawls. Distribution of I. coindetii has been studied in the eastern Mediterranean by several authors (Belcari and Viva, 1989; Roper et al., 1998; González et al., 1992 b; Guerra, 1992; Katagan et al., 1993 and Perdichizzi et al., 2011). There is some data concerning its biology (Nigmatullin and Vovk, 1972; Sánchez, 1981; Sánchez, 1982; Ragonese and Jereb, 1992; González, 1994; Jereb and Ragonese, 1995; Belcari, 1996; González, et al., 1996; Ceriola et al., 2006; Arkhipkin et al., 2000; Arvanitidis et al., 2002; Ceriola and Milone, 2016.and ; Salman, 2017). Recently, other studies have focused on the species in relation to fisheries and management (Sánchez, 1990; González et al. 1992a,;1992b, Tursi and D'Onghia, 1992 ; Martin, 1993 and Arvanitidis et al., 2002). The objective of the present investigation was to study the growth, seasonal changes in the gonads, and the length at maturity $\left(\mathrm{L}_{50}\right)$, mortality rates and exploitation rate of important species, Illex coindetii from the deep water off the Egyptian Mediterranean Sea for the future management of their stocks.

\section{MATERIALS AND METHODS}

\section{Study area}

Izbat El Burg fishing port is home to approximately 10,000 fishermen (constituting 1\% of the total Egyptian fishermen). It is located in the northern part of Egypt opposite to Ras El Bar city; it lies 15-km, northeast of the Damietta Governance (Fig. 1).

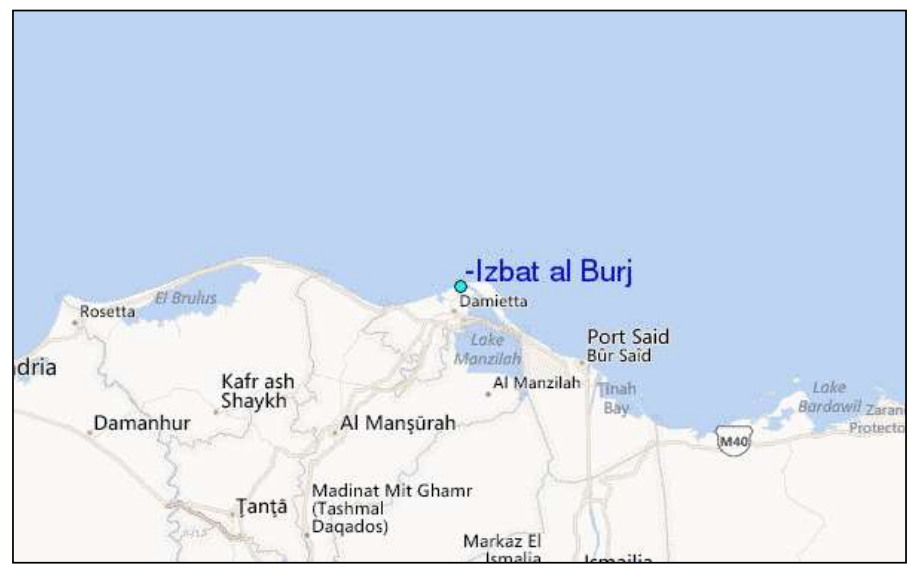

Fig. 1: A map of the Egyptian Mediterranean Coast showing the sampling landing sites: Izbat El Burg port, Damietta Governorate.

\section{Sampling analysis:}

Illex coindetii samples were collected seasonally during 2016 from the vessels operating by the deep-water fishery off the Mediterranean, and landing their production at Izbat El Burg fishing port.

The mantel length-body weight (BW) relationship, a total of 370 specimens of Illex coindetii were taken for the estimation of all biological characteristics. The mantle length-weight relationship was estimated according to the equation of Le Cren (1951): $\mathrm{BW}=\mathrm{a} \mathrm{DML}{ }^{\mathrm{b}}$, where (BW) is the total body weight, (DML) is the dorsal mantle length, while (a) and (b) are constants. 


\section{Aging:}

Age determination was computed by applying Bhattacharya method (1967) depending on the dorsal mantle length frequency data (DML), which were analyzed using FISAT II (Gayanilo et al., 1996). ELEFAN I method was used to estimate the von Bertalanffy (1938) growth parameters, asymptotic length, $\mathrm{L}_{\infty}$ and the annual growth coefficient $\mathrm{K}$. The constant " $\mathrm{t}_{0}$ " was estimated by (Pauly 1983) according to the following equation: $\log \left(-\mathrm{t}_{0}\right) \approx-0.3922-0.2752 \log \mathrm{L} \infty-1.038 \log \mathrm{K}$

Gonadsomatic index: (GSI) was determined by using the following equation:

GSI = (gonad weight /gutted body weight $\mathrm{x} 100)$.

Length at sexual maturity: Sex and maturity stages were identified in all samples. Length at sexual maturity $\left(\mathrm{Lm}_{50}\right)$ is the length at which $50 \%$ of Illex coindetii reach their sexual maturity; it was estimated by fitting the percentage maturity against midlengths (king, 1995). $\mathrm{Lm}_{50}$ is represented at the point on $\mathrm{X}$-axis corresponding to $50 \%$ point on Y-axis.

Age at maturity it's the average age at which fish of a given population mature for the first time. It is calculated from the size at first maturity using the inverse of the von Bertalanffy growth, function: $\mathrm{t}_{\mathrm{m}}=\mathrm{t}_{0}-\ln \left(1-\mathrm{L}_{\mathrm{m}} / \mathrm{L}_{\text {inf }}\right) / \mathrm{K}$

Mortality was estimated by using Jones and van Zalinge method's (1981). This method was applied to investigate the annual instantaneous total mortality (Z) using the cumulated catch curve of the length composition information as follows:

$\mathrm{Ln}(\mathrm{Cn})=\mathrm{a}+(\mathrm{Z} / \mathrm{K}) \mathrm{Ln}(\mathrm{L} \infty-\mathrm{L})$, where $\mathrm{Ln}(\mathrm{Cn})$ is the cumulative frequency. A linear regression between $\mathrm{Ln}(\mathrm{Cn})$ and $\mathrm{Ln}(\mathrm{L} \infty-\mathrm{L})$ was done and the slope $=-\mathrm{Z}$. The annual mortality (A) is computed as $\mathrm{A}=1-\mathrm{S}$ where, $\mathrm{S}$ is survival rate, which is computed from the equation, $S=\mathrm{e}^{-\mathrm{z}}$ (Ricker, 1975).

Natural mortality $(M)$ was estimated by Charnov et al. (2013) method, where von Bertalanffy growth parameters are used: $M=(L / L \infty)-1.5 \times K$, where $L \infty$ and $K$ are (asymptotic length and growth coefficient), and $L=$ fish length at age.

Fishing mortality $(\mathrm{F})$ was expressed as $\mathrm{F}=\mathrm{Z}-\mathrm{M}$ and the exploitation rate $(\mathbf{E})$ was estimated as $\mathrm{F} / \mathrm{Z}$ according to (Gulland, 1971).

Length and age at first capture $\left(\mathrm{L}_{\mathrm{c}}\right)$ was computed by $\mathrm{L}_{c}=40 \% \mathrm{~L}_{\max }$ (Beverton and Holt, 1964), where $\mathrm{L}_{\max }$ is the maximum length while the corresponding age at the first capture $\left(\mathrm{T}_{\mathrm{c}}\right)$ was computed by converting $\mathrm{L}_{\mathrm{c}}$ to age using the von Bertalanffy growth equation as follows $: \mathrm{T}_{\mathrm{c}}=\mathrm{t}_{0}-\left(1 / \mathrm{k} * \operatorname{Ln}\left[1-\left(\mathrm{L}_{\mathrm{c}} / \mathrm{L}_{\infty}\right)\right]\right)$.

The optimum length at capture was calculated by (Beverton, 1992) formula: $\mathrm{L}_{\mathrm{opt}}=3 \mathrm{~L}_{\infty} /(3+\mathrm{M} / \mathrm{K})$

\section{RESULTS}

\section{Length frequency distribution}

Samples of Illex coindetii were collected seasonally from the trawl deep water vessels operating in the Mediterranean Sea and represented in Fig (2). It is clear that the dorsal mantle length range was 11.3 to $30.7 \mathrm{~cm}$ with mean $14.8 \pm 3.7$ and the largest specimen was recorded in winter, while in spring the smallest specimen was noted as the length range was $10.5-13 \mathrm{~cm}$ with mean $13.6 \pm 1.9$ whereas the range

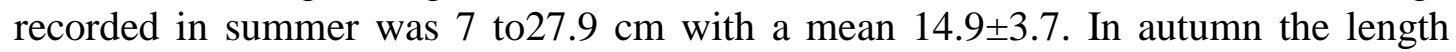
ranged from $5.6-19.2 \mathrm{~cm}$ and the mean was $11.7 \pm 3.3$. 

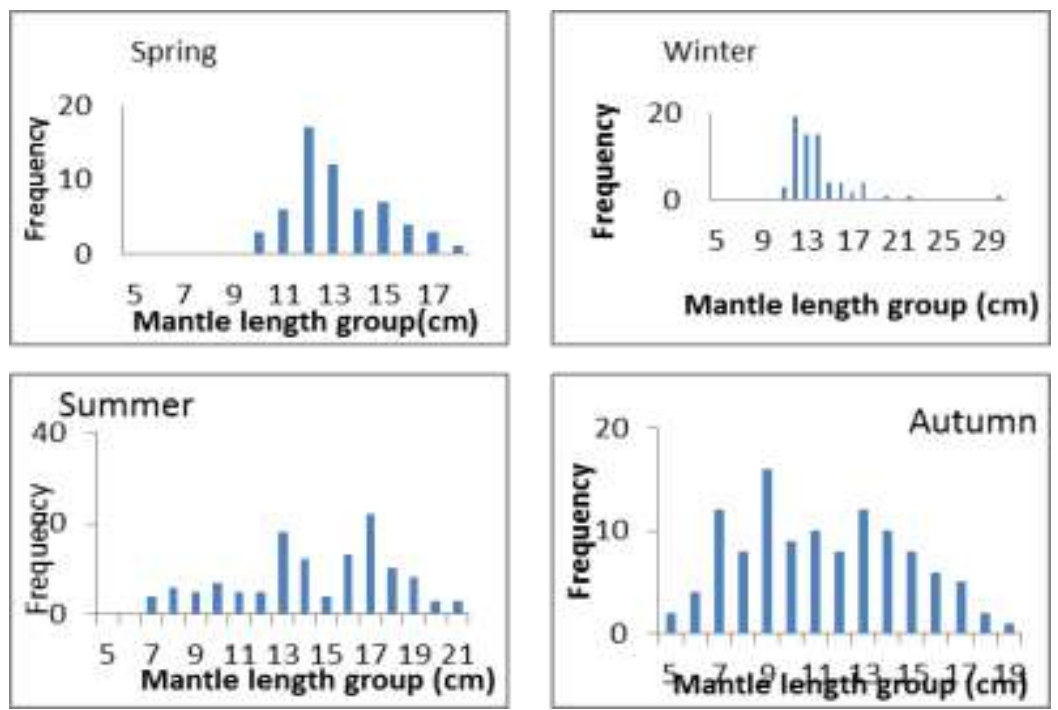

Fig. 2: Seasonal Mantle - Length frequency distribution for Illex coindetii from the deep water off the Egyptian Mediterranean Sea.

\section{Length-weight relationship:}

A total of 370 specimens of Illex coindetii (189 males and 157 females and 24 unidentified sex were analyzed. Males were slightly smaller and lighter than females $(\boldsymbol{p}<$ 0.001 for both total mantle length and body weight). Mean total mantle length for males was $12.17 \pm 2.8 \mathrm{~cm}(\min =5 \mathrm{~cm} ; \max =20 \mathrm{~cm})$, while in females, it was $15.77 \pm 3.3 \mathrm{~cm}(\min =7$ $\mathrm{cm}$; $\max =30.7 \mathrm{~cm})$. Mean weight for males $(91.3 \pm 55.26 \mathrm{~g} ; \min =6.5 \mathrm{~g}$; $\max =229 \mathrm{~g})$, which was lower than that for females $(133.2 \pm 82.1 \mathrm{~g}$; $\min =14 \mathrm{~g}$; $\max =812.8, \mathrm{~g})$ Fig (3). The values for mean weight by sex were simply compared by two-sample t-test. The results show that females were larger than males and significant difference $(\mathrm{p}<0.05)$ between males and females (differences 41.9, pooled standard deviation 68.74, standard error7.4 to 23, 95\% CL 27.3 to 56.5 test statistic t 5.645, DF 344, significance level $(\mathrm{p}=0.0001)$ significant difference.

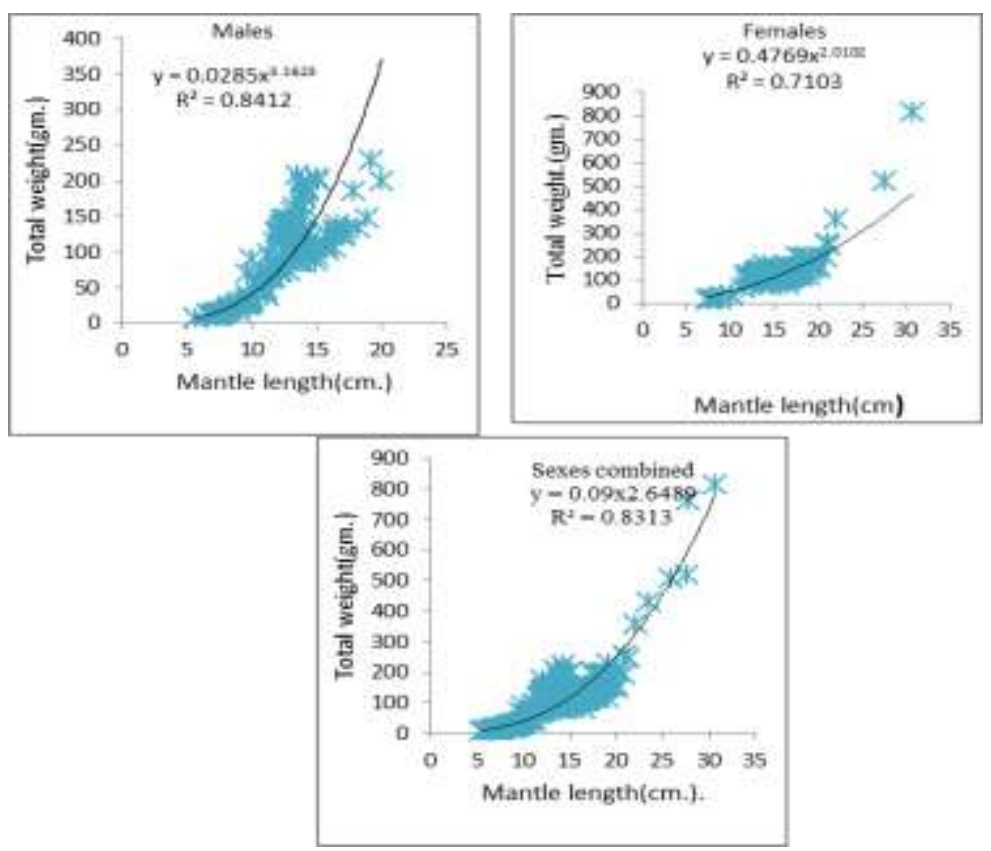

Fig. 3: Dorsal Mantle Length -Weight relationship of Illex coindetii males, females and sexes combined.. 
The regression between DML and BW for females and sexes combined showed a sharp negative allometric growth as all values of $b(2.01,2.648)$ were significantly different from the isometric 3 ( $\mathrm{p}<0.05)$. In contrast, the calculated $b$ value for males (3.16) was significantly higher than 3 and therefore revealed a positive allometric growth indicating that weight increases faster than length Table. (1).

Table 1: Mantle length-weight relationship parameters of Illex coindetii (males, females, and sexes) from the deep water off the Egyptian Mediterranean Sea.

\begin{tabular}{|c|c|c|c|c|c|c|}
\hline \multirow{2}{*}{$\begin{array}{c}\mathrm{L}-\mathrm{W} \\
\text { parameters }\end{array}$} & \multicolumn{2}{|l|}{ Males } & \multicolumn{2}{|c|}{ Females } & \multicolumn{2}{|c|}{ Sexes combined. } \\
\hline & Min-Max & Mean \pm SD & Min-Max & Mean \pm SD & Min-Max & Mean \pm SD \\
\hline Length & $5.6-20$ & $12.17 \pm 2.8$ & $7.4-30.7$ & $15.77 \pm 3.3$ & $5.6-30.7$ & $13.9 \pm 3.8$ \\
\hline Wight & $6.5-229$ & $91.3 \pm 55.26$ & $14-812.8$ & $133.2 \pm 82.1$ & $6.5-812.8$ & $114.9 \pm 86.3$ \\
\hline (a) & 0.02 & & 0.47 & & 0.09 & \\
\hline $\begin{array}{l}\text { (b) } \\
(\mathrm{r}) \\
(\mathrm{No} .)\end{array}$ & $\begin{array}{l}3.16 \\
0.84 \\
189\end{array}$ & & $\begin{array}{l}2.01 \\
0.71 \\
157\end{array}$ & & $\begin{array}{l}2.64 \\
0.83 \\
370\end{array}$ & \\
\hline
\end{tabular}

\section{Aging}

The length frequency data of Illex coindetii was analyzed by Bhattacharya (1967) method for (189) males, (157) females and sexes combined (370) and the results illustrated at (Fig. 4, Table 2). It is shown that the males achieved lengths of $7.24,12.30$ and $16.44 \mathrm{~cm}$, at the end of zero, $1^{\text {st }}$ and $2^{\text {nd }}$ year, respectively, where females attained 7.5.13.45,17.33 and $20.4 \mathrm{~cm}$ at the end of zero, to $3^{\text {rd }}$ year and the pooled sexes reached 7.3,12.46.17.19 and $20.84 \mathrm{~cm}$ at the end of zero, to $3^{\text {rd }}$ respectively. The age group I was recorded by a high percentage $(72.6,64.5$ and $58.1 \%$ ) for males, females, and sexes combined respectively.
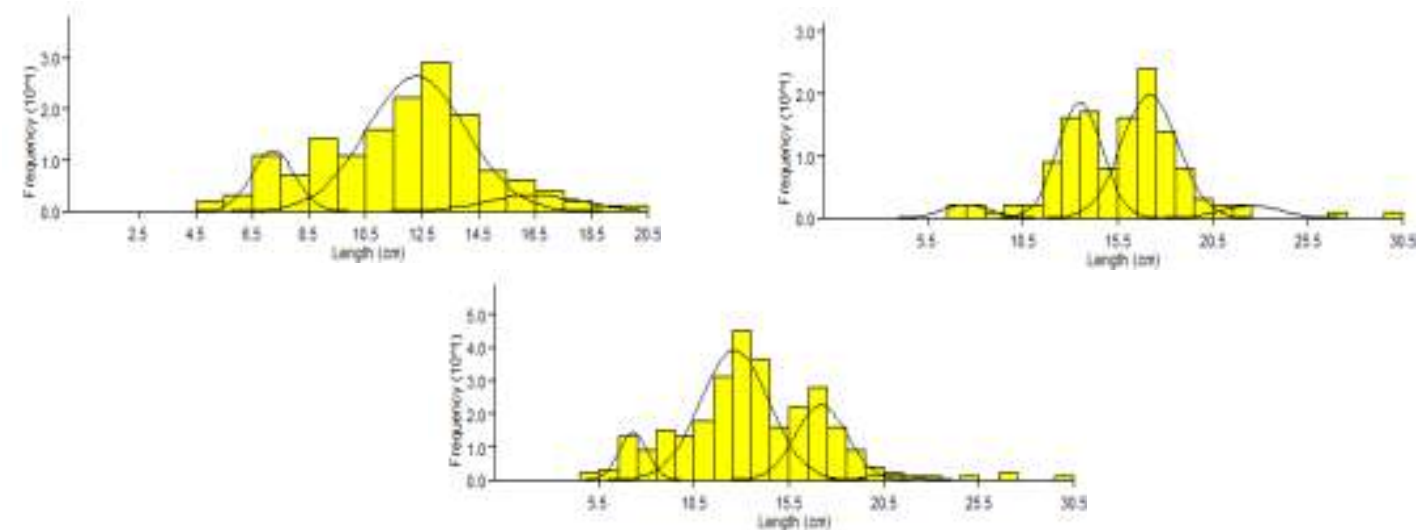

Fig. 4: Length frequency of Illex coindetii males, females and sexes combined separated into normally distributed components using Bhattacharya method.

Table 2: Mean length with standard deviation (SD) and Age composition for each age group of Illex coindetii as estimated by the Bhattacharya method.

\begin{tabular}{|c|c|c|c|c|c|c|c|c|}
\hline Sex & \multicolumn{6}{|c|}{ Mean length at age group (Mean \pm SD) with Age composition } & & \\
\hline & 0 & $\%$ & I & $\%$ & II & $\%$ & III & $\%$ \\
\hline Males & $7.24 \pm 0.76$ & $24.20 \%$ & $12.3 \pm 1.76$ & $72.60 \%$ & $16.44+\_1.69$ & $3.20 \%$ & & \\
\hline Females & $7.5 \pm 1.2$ & $4.50 \%$ & $13.45 \pm 1.756$ & $64.50 \%$ & $17.33 \pm 1.25$ & $27.75 \%$ & $20.4 \pm 1$ & $3.30 \%$ \\
\hline $\begin{array}{c}\text { Sexes } \\
\text { combined }\end{array}$ & $7.3 \pm 0.74$ & $19 \%$ & $12.46 \pm 1.61$ & 58.1 & $17.19 \pm 1.35$ & $19.60 \%$ & $20.84 \pm 1.22$ & $3.30 \%$ \\
\hline
\end{tabular}

\section{Growth}

The growth parameters were evaluated using ELEFAN I and the results showed that $\mathrm{L} \infty$ for males, females, and pooled sex was $21,31.5$ and $31.5 \mathrm{~cm}$, respectively, 
and the values of annual growth rate $(\mathrm{k})$ were $0.570,0.22$ and 0.28 /year, while $\mathrm{t}_{0}$ was calculated at $-0.314,-0.755$ and -0.587 , respectively.

\section{Sex ratio}

To study sex ratio about 346 individuals of Illex coindetii 189(55\%) males and $157(45 \%)$ females were investigated. Sex ratio showed highly significant values from the expected 1:1 in all length groups were $\left(X^{2}\right.$ ranged from 3.24 to $\left.27.0, \mathrm{P}<0.05\right)$ excepted of length groups $13-14 \mathrm{~cm}$, was no significant difference where both male and female populations occurred $(p>0.05)$ (Table.3) where females were dominant after the length group $(19-20 \mathrm{~cm}$.).

Table 3: Variation in Sex ratio according to size group of Illex coindetii from the deep water off the Egyptian Mediterranean Sea.

\begin{tabular}{|c|c|c|c|c|c|c|r|r|}
\hline Mid-length & Total. No & \multicolumn{2}{|c|}{ Male } & \multicolumn{2}{|c|}{ Female } & Sex ratio & P -value & $X^{2}$ \\
\hline & & No. & $\%$ & No. & $\%$ & & & \\
\hline $5-6$ & 5 & 5 & 100.00 & 0 & 0.00 & ----- & ----- & ----- \\
\hline $7-8$ & 22 & 18 & 81.82 & 4 & 18.18 & $1: 0.22$ & $* 0.003$ & 8.91 \\
\hline $9-10$ & 30 & 27 & 90.00 & 3 & 10.00 & $1: 0.11$ & $* 0.000$ & 19.20 \\
\hline $11-12$ & 72 & 58 & 80.56 & 14 & 19.44 & $1: 0.24$ & $* 0.000$ & 26.88 \\
\hline $13-14$ & 100 & 59 & 59.00 & 41 & 41.00 & $1: 0.69$ & 0.072 & 3.24 \\
\hline $15-16$ & 50 & 14 & 28 & 36 & 72 & $1: 2.60$ & $* 0.002$ & 9.68 \\
\hline $17-18$ & 48 & 6 & 12.50 & 42 & 87.50 & $1: 7$ & $* 0.000$ & 27.00 \\
\hline $19-20$ & 13 & 2 & 15.38 & 11 & 84.62 & $1: 5.50$ & $* 0.013$ & 6.231 \\
\hline $21-22$ & 4 & 0 & 0.00 & 4 & 100.00 & ----- & ----- & ----- \\
\hline 2728 & 1 & 0 & 0.00 & 1 & 100.00 & ----- & ----- & ----- \\
\hline $29-30$ & 1 & 0 & 0.00 & 1 & 100.00 & ----- & ----- & ----- \\
\hline
\end{tabular}

* Significance difference

\section{Seasonal variation of sex ratio:}

Seasonal variations of sex ratio for Illex coindetii (Table 4) clear that males dominated the catch in all seasons with higher ratio during summer $(65 \%)$.Generally, for the whole period of investigation; males accounted $55 \%$ of the total catch with sex ratio (1: 0.83 ). The chi-square value computed was $2.96 ; \mathrm{p}=0.085(\mathrm{p}>0.05)$ this value showed no significant difference between both sexes.

Table 4: Seasonal variation in the sex ratio of Illex coindetii from the deep water off the Egyptian Mediterranean Sea.

\begin{tabular}{|l|cc|cc|c|c|c|l|l|}
\hline Season & \multicolumn{2}{|c|}{ Males } & \multicolumn{2}{l|}{ Females } & \multicolumn{2}{l|}{ Sex ratio } & Chi-Square & Sig. \\
\hline & No & $\%$ & No & $\%$ & \multicolumn{2}{l|}{ M: F } & Value & P-value \\
\hline Winter & 34 & $49 \%$ & 35 & $51 \%$ & $1:$ & 1.03 & 0.14 & 0.904 \\
\hline Spring & 52 & $48 \%$ & 56 & $52 \%$ & $1:$ & 1.08 & 0.148 & 0.700 \\
\hline Summer & 73 & $65 \%$ & 39 & $35 \%$ & $1:$ & 0.53 & 10.32 & $* 0.001$ \\
\hline Autumn & 30 & $53 \%$ & 27 & $47 \%$ & $1:$ & 0.90 & 0.158 & 0.691 \\
\hline Total & 189 & $55 \%$ & 157 & $45 \%$ & $1:$ & 0.83 & 2.96 & 0.085 \\
\hline
\end{tabular}

\section{Gonado-Somatic Index (GSI):}

The seasonal mean values of GSI of Illex coindetii (Fig. 5), it is clear that there were two peaks in GSI of males and females, one in spring and the other in autumn 


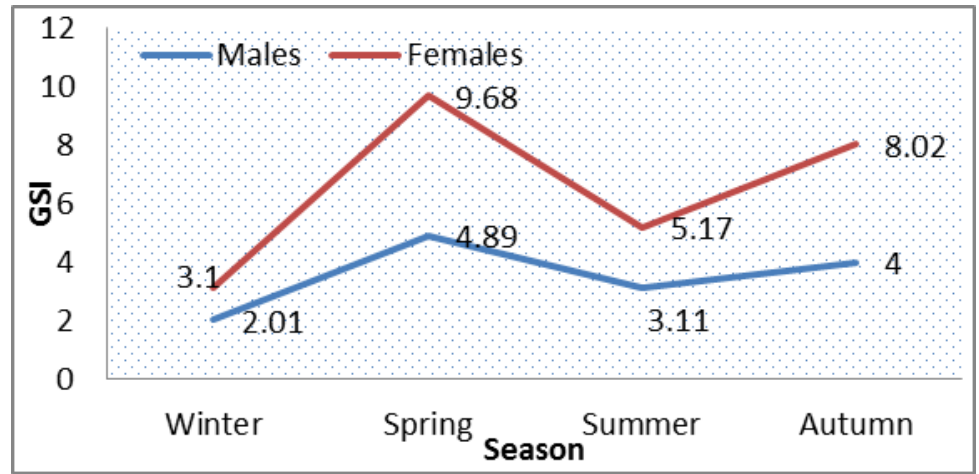

Fig. 5: Seasonal variation in Gonad somatic index of Illex coindetii from the deep water off the Egyptian Mediterranean Sea.

\section{Length at first sexual maturity}

$\mathrm{Lm}_{50}$ values ranged between 11.0 and $11.9 \mathrm{~cm}$ with a mean length of $11.51 \pm$ 0.325 for males and between 14-14.9 with mean length14.35 \pm 0.298 for females Fig (6). T-test showed that there was a significant difference for $\left(\mathrm{L}_{\mathrm{m} 50}\right)$ between sexes in Illex coindetii. ( $\mathrm{P}<0.05$ ) (Difference 2.84), ( pooled standard deviation 0.311), (SD, 0.105), (95\%CI2.625 to 3.05), (statistic $t$ 26.96) with high significance level $\mathrm{p}<0.0001$.

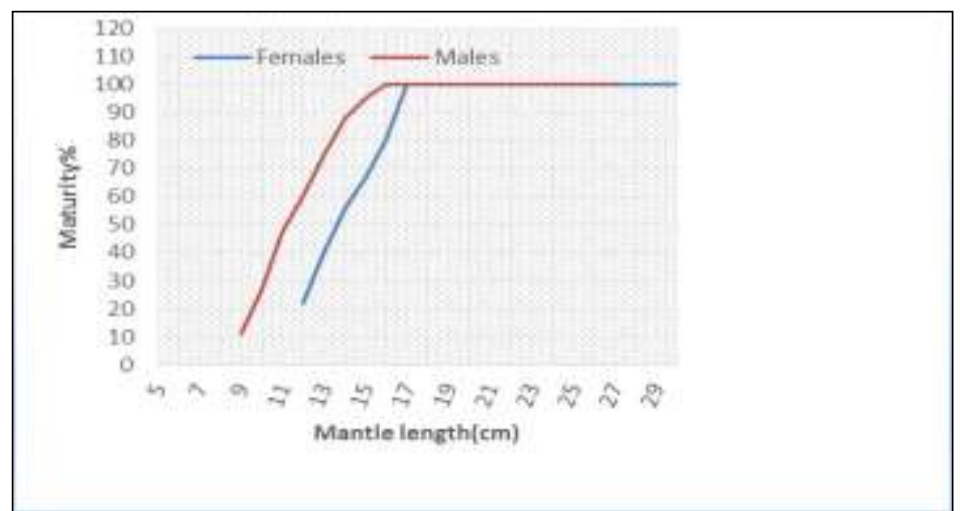

Fig. 6: Length at first sexual maturity for Illex coindetii from the deep water off the Egyptian Mediterranean Sea.

The length age at first capture $\left(\mathbf{L}_{\mathbf{c}}\right)$ was estimated as 8, 12 and 12 for males, females, and sexes combined respectively, which corresponding to age $0.527,1.566$ and 1.23 .

The optimum length at capture $\left(\mathrm{L}_{\text {opt }}\right)$

$\mathbf{L}_{\mathbf{~ o p t}}$ was calculated as $13.36,17.38$ and $18.6 \mathrm{~cm}$ for males, females, and sexes combined of Illex coindetii.

\section{Mortality and exploitation rates}

The annual instantaneous total mortality $(\mathrm{Z})$ were $2.94,2.76$ and 2.79 / year for males females and sexes combined Fig (7). The calculated survival rates (S) were $0.05 \%, 0.06 \%$, and $0.06 \%$ respectively, then the mean annual mortality was 99.95\% for males, $99.94 \%$ for females and 99.94 sexes combined. The mean values of natural mortality (M) were $1.05,0.74$ and $0.74 /$ year, respectively. The fishing mortality was estimated at 1.98, 2.02 and 2.05/year. The exploitation ratio was lower in males 0.64 than in females 0.73 and 0.73 for sexes combined. 

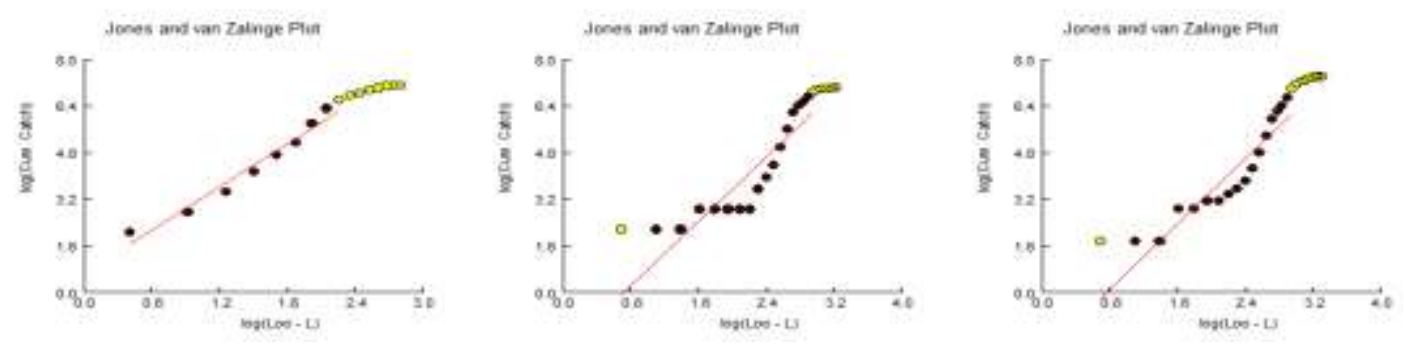

Fig. 7: Total mortality rates for males, females, and sexes combined for Illex coindetii by Jones and van Zalinge's (1981).

\section{DISCUSSION}

Length-frequency data provide valuable information about the life history of a fish species and give information on the dynamics of fish populations and help identify problems such as age-unsuitability, slow growth or excessive mortality. However, the reliability of the analysis largely depends on the sampling approach and the size of the samples investigated. Illex coindetii is a medium-sized squid, commonly reaching 200-250 mm ML throughout its distributional range (Roper et $a l ., 2010 \mathrm{a})$. Large specimens of longer than $300 \mathrm{~mm}$ ML were captured on both sides of the Atlantic and the Mediterranean. In the present study, the maximum mantle length is recorded for females at $30.7 \mathrm{~cm}$ while for males equal $20 \mathrm{~cm}$. This corresponds to (González et al., 1996) in northeast Atlantic recorded $379 \mathrm{~mm}$ mantle length for females and $279 \mathrm{~mm}$, for males. While the maximum size of $320 \mathrm{~mm} \mathrm{ML}$ reported for males by (Sánchez et al. 1998b; Roper et al., 1998; Ceriola et al., 2006; and Perdichizzi et al., 2011).

In the current study, there was a significant difference of the dorsal mantle length-weight relationship between males and females $(p<0.05)$ with ' $r$ ' values of 0.84 and 0.71 for males and females respectively. The growth exponent (' $b$ ' values) was 2.01 for females indicating sharp negative allometric growth. The predicted ('b') for males was 3.16 significantly more than 3 appearing a positive allometric growth indicating that weight increases faster than length. The significantly higher slope was observed in male compared to female indicating faster growth of male.

This result approves with the previous results were achieved from different regions of the Mediterranean Sea and the eastern Atlantic, as well as the different year. (Ragonese and Jereb, 1992; González et al., 1992a; Jereb and Ragonese, 1995; Belcari, 1996; Hernandez- Garcia and Castro, 1998; Sanchez et al., 1998; Arkhipkin, Jereb and Ragonese, 2000; Arvanitidis et al., 2002) are found that allometric lengthweight relationship which is positive in males $(b>3)$ and negative in females $(b<3)$. In contrast with (Sanchez et al., 1998) from Spanish coasts and (Ceriola et al., 2006) from the South Adriatic stated that both sexes show positive allometry. Moreover, (Belcari, 1996) stated that mature animals show positive allometry growth while immature show negative allometry. (Belcari, 1996 and Ceriola et al., 2006) found that the morphometric changes occurring during the gonad maturation induce a positive allometric growth in males and isometric growth in females. The change of " $b$ " values depends primarily on the shape and the fatness of the species, and various factors like temperature, salinity, food, sex and stage of maturity (Sparre and Venema, 1992).

Estimation of age and growth is essential for proper understanding the life history and reproductive strategies of harvested species, as well as its parameters, are necessary for assessment and fisheries management plan. The growth and lifespan of Illex coindetii were examined for the first time from fishing in deep water off the 
Egyptian Mediterranean Sea noted two age groups with zero group of male and three age groups with zero group of females and sexes combined. This is comparable to (González et al., 1996; Sánchez et al., 1998; Arkhipkin et al., 2000 Ceriola et al. 2016) stated that the lifespan of females $I$. coindetii usually showed a faster growth rate and longer than males. Table (5) shows that lifespan estimates of I. coindetii vary from (6 to 24 months). Arkhipkin et al., 2000 in the Sicily Channel stated that the same lifespan for males and females ranged from 6-7 months based on statoliths reading. While Illex coindetii lives less and grows faster than in the northwestern Mediterranean Sea. (Sánchez, 1995) found that I. coindetii lifespan was 12-18 months for females and males, used length frequency distribution. (González et al., 1994) in the Galician waters reported that the lifespan was 15 months for two sexes, used Model progression analysis. (Mangold-Wirz, 1963a) in the western Mediterranean Sea, used length frequency analysis and concluded that the life span 20 and 24 months for males and females respectively. (Ceriola and Milone 2016) recorded female lifespan ranged from 128 to 234 days longer than males 124-178 days. The variances in lifespan are due to the differences of individual size in the sample and in environmental condition especially temperature which affected on growth.

Table 5: Maximum mantle length and lifespan of Illex coindetii from the Northeast Atlantic and the Mediterranean Sea.

\begin{tabular}{|c|c|c|c|c|c|c|}
\hline \multirow[t]{2}{*}{ Method } & \multirow{2}{*}{\begin{tabular}{|c|}
$\mathrm{M}$ \\
$\mathrm{ML}(\mathrm{mm})$
\end{tabular}} & \multirow{2}{*}{$\frac{\mathrm{F}}{\mathrm{ML}(\mathrm{mm})}$} & \multicolumn{2}{|c|}{$\begin{array}{l}\text { Lifespan } \\
\text { (months) }\end{array}$} & \multirow[t]{2}{*}{ Region } & \multirow[t]{2}{*}{ Reference } \\
\hline & & & Female & Male & & \\
\hline $\begin{array}{l}\text { cohort } \\
\text { monitoring }\end{array}$ & 200 & 263 & 24 & 20 & $\begin{array}{l}\text { Western } \\
\text { Mediterranean }\end{array}$ & $\begin{array}{l}\text { Mangold-Wirz } \\
(1963 a)\end{array}$ \\
\hline $\begin{array}{l}\text { cohort } \\
\text { monitoring }\end{array}$ & 140 & 170 & 17.7 & 16.6 & Catalan Sea & Sánchez (1984) \\
\hline \multirow[t]{2}{*}{ MPA } & 279 & 379 & 15 & 15 & Galician waters & González (1994) \\
\hline & & & 12 & 18 & $\begin{array}{l}\text { Northwestern } \\
\text { Mediterranean } \\
\text { Sea } \\
\end{array}$ & Sánchez, 1995 \\
\hline statoliths & 230 & 300 & 10 & 8 & West Sahara & $\begin{array}{l}\text { Arkhipkin } \\
\text { (1996) }\end{array}$ \\
\hline statoliths & & & 18 & 18 & $\begin{array}{l}\text { Western } \\
\text { Mediterranean } \\
\text { Sea. }\end{array}$ & $\begin{array}{l}\text { Sánchez et al. } \\
\text { (1998b) }\end{array}$ \\
\hline statoliths & & & $6-7$ & $6-7$ & Sicilian Channel & $\begin{array}{l}\text { Arkhipkin et al. } \\
(2000)\end{array}$ \\
\hline MPA & 217 & 286 & 18 & 11 & $\begin{array}{l}\text { Southern Celtic Sea } \\
\text { Bay of Biscay }\end{array}$ & $\begin{array}{l}\text { Arvanitidis et al. } \\
(2002)\end{array}$ \\
\hline statoliths & 156 & 210 & $\begin{array}{c}128-234 \\
\text { days }\end{array}$ & $\begin{array}{c}124-178 \\
\text { days }\end{array}$ & $\begin{array}{l}\text { Central } \\
\text { Mediterranean }\end{array}$ & $\begin{array}{l}\text { Ceriola and } \\
\text { Milone } 2016\end{array}$ \\
\hline $\begin{array}{l}\text { Bhattacharya } \\
\text { (1967) }\end{array}$ & $20 \mathrm{~cm}$. & $30.7 \mathrm{~cm}$. & $\begin{array}{c}2 \text { years } \\
\text { With } \\
\text { zero } \\
\text { group. }\end{array}$ & $\begin{array}{l}3 \text { years } \\
\text { With } \\
\text { zero } \\
\text { group. }\end{array}$ & $\begin{array}{l}\text { Deep water off the } \\
\text { Egyptian } \\
\text { Mediterranean Sea. }\end{array}$ & Present study \\
\hline
\end{tabular}


In the present study sex ratio by length frequency of Illex coindetii revealed that males represented $55 \%$ of the total catch with a sex ratio (1:0.83). It is close to the previous study in the Mediterranean and in the eastern Atlantic recorded about $50 \%$ .While it is vary slightly between areas. In the Mediterranean, Sicilian Channel it fluctuates between 46.4 and $46.6 \%$ whereas in the Catalan Sea counted $53.2 \%$. In the eastern Atlantic it varies between $43.8 \%$ and $55.9 \%$ in the western African coast $16^{\circ}-29^{\circ} \mathrm{N}$ and $11^{\circ}-15^{\circ} \mathrm{N}$ respectively. In the present study sex ratio showed highly significant values in all length groups were $\left(X^{2}\right.$ ranged from 3.24 to $\left.26.88, \mathrm{P}<0.05\right)$ except length group at sexual maturity13-14 cm were no significant difference $(\mathrm{P}$ $>0.05)$. Length at first sexual maturity $L_{m 50}$ values was $11.51 \mathrm{~cm}$ for males and 14.35 $\mathrm{cm}$ for females. The nearly similar results observed in different parts of the Mediterranean Sea. ( Arvanitidis et al., 2002) from the neighboring Greek Seas found that $\mathrm{ML}_{50}$ males $113 \mathrm{~mm}$ ML; females $179 \mathrm{~mm}$ ML. (Ceriola et al., 2006) from Adriatic reported $\mathrm{ML}_{50}$, males $137 \mathrm{~mm}$ ML; females $146 \mathrm{~mm}$ ML. (Jereb and Ragonese, 1995) from Sicilian Channel estimated ML50, were $120 \mathrm{~mm}$ and $150 \mathrm{~mm}$ for males and females respectively. (Perdichizzi et al., 2011) from the southern Tyrrhenian Sea found that ML50, males $105 \mathrm{~mm}$ ML; Females $150 \mathrm{~mm}$ ML. (Salman, 2017) in the Aegean Sea, Eastern Mediterranean, was observed. ML $L_{50}$ was $139.3 \mathrm{~mm}$ ML for males' and $164.8 \mathrm{~mm}$ ML for females. All previous results attained that the males were reached maturity at a smaller size than females.

Seasonal variation in gonad somatic index clear that females recorded higher GSI than males in all seasons. There were two peaks in GSI of females, and males one in spring and the other in autumn. This result agrees with the previous results were attained from other areas of the Mediterranean.( Sanchez, 1995 and Ceriola et al., 2006)) from the Mediterranean coasts of Spain were reported that the spawning of I. coindetii occurred throughout the year with increased in some seasons. Our results agree with (Salman, 2017) in the Aegean Sea, eastern Mediterranean, recorded two peaks in GSI of females, one in spring and the other in autumn/early winter. While in comparing (Perdichizzi et al., 2011), recorded that two reproduction peaks observed, one in early summer and the other in autumn. The previous results point out spawning may occur year-round, but seasonal peaks exist and differ widely through the geographic range.

The total mortality coefficient $(\mathrm{Z})$ for the sexes combined of Illex coindetii, was 2.79. The calculated survival rate (S) was 0.06 that's means about $0.06 \%$ only of Illex coindetii survive per year after their first year of life. The calculated annual mortality rate was $(\mathrm{A})=99.94 \%$. The obtained results show that the natural mortality coefficient (M) was found to be 0.74 , with a percentage of $0.27 \%$ of the total mortality. While fishing mortality was estimated at 2.05 with the percentage of $0.73 \%$. The previous result illustrated that Illex coindetii from the deep water off the Egyptian Mediterranean Sea is exposed to high fishing pressure. The current exploitation rate was recorded as 0.73 this value was more than 0.50 for the optimum condition of exploitation (Gulland, 1971). This means that the stock of Illex coindetii was overexploited. The length at first capture $\left(\mathrm{L}_{\mathrm{c}}\right)$ which related to the trawl cod-end mesh size was examined as $8 \mathrm{~cm}, 12 \mathrm{~cm}$ and $12 \mathrm{~cm}$ for males, females, and sexes combined respectively. It is obvious that $\mathrm{L}_{\mathrm{c}}$ is lower than the length at maturity $\left(\mathrm{L}_{\mathrm{m} 50}\right)$, which was found to be $11.51 \mathrm{~cm}$ for males and 14.35 for females. The length, which gives the maximum possible yield $\left(\mathrm{L}_{\mathrm{opt}}\right)$ the optimum length at capture was estimated at $13.36,17.38$ and $18.6 \mathrm{~cm}$ for males, females, and sexes combined respectively. It is clear that it was larger than a length at first maturity and length at first capture. The previous analysis suggested that Illex coindetii exposed to 
overexploitation where the equilibrium between the amount of fishing and the conservation not found for this species in this area.

\section{CONCLUSION}

Illex coindetii stock from the deep water off the Egyptian Mediterranean Sea must be managed by decreasing the present fishing pressure and increasing the length at first capture $\left(\mathrm{L}_{\mathrm{c}}\right)$ by taking size at first maturity $\left(\mathrm{L}_{\mathrm{m} 50}\right)$ as a reference point of minimum legal size to prevent stock depletion. The spawning season was found to take place during spring and autumn, so it is recommended to reduce fishing activity during this period.

\section{REFERENCES}

Arkhipkin, A.; Jereb, P. and Ragonese, S. (2000). Growth and maturation in two successive seasonal groups of the short-finned squid, Illex coindetii from the Strait of Sicily (central Mediterranean). ICES Journal of Marine Science, 57(1): 31-41.

Arvanitidis, C.; Koutsoubas, D.; Robin, J. P.; Pereira, J.; Moreno, A.; da Cunha, M. M. and Eleftheriou, A. (2002). A comparison of the fishery biology of three Illex coindetii Verany, 1839 (Cephalopoda: Ommastrephidae) populations from the European Atlantic and Mediterranean waters. Bulletin of marine science, 71(1): 129-146.

Belcari, P. A. (1996). Length-weight relationships in relation to sexual maturation of Illex coindetii (Cephalopoda: Onunastrephidae) in the northern Tyrrhenian Sea (Western Mediterranean). Sci Mar, 60 (2-3): 379-384.

Belcari, P.; Fedi, E. and Viva, C. (1989). Distribuzione e sex-ratio di Illex coindetii Verany 1839 (Cephalopoda, Oegopsida) nell'arcipelago Toscano Meridionale. Nova Thalassia, 10(Suppl 1): 507-509.

Bertalanffy Von, L. (1938). A quantitative theory of organic growth (inquiries on growth laws. II). Human biology, 10(2): 181-213.

Beverton, R. J. H. and Holt, S. J. (1964). Tables of yield functions for fishery assessment (No. 38). Fisheries Division, Biology Branch, Food and Agriculture Organization of the United Nations.

Beverton, R. J. H. (1992). Patterns of reproductive strategy parameters in some marine teleost fishes. Journal of Fish Biology, 41: 137-160.

Bhattacharya, C. G. (1967). A simple method of resolution of a distribution into Gaussian components. Biometrics, pp.115-135.

Ceriola, L.; Ungaro, N. and Toteda, F. (2006). Some information on the biology of Illex coindetii (Verany, 1839) (Cephalopoda, Ommastrephidae) in the southwestern Adriatic Sea (central Mediterranean). Fisheries Research, 82(1-3): 4149.

Ceriola, L. and Milone, N. (2016). Growth and reproduction of the squid Illex coindetii (Verany, 1839) in the central Mediterranean Sea. Mediterranean Marine Science, 18(1): 107-120.

Charnov, E. L.; Gislason, H. and Pope, J. G. (2013). Evolutionary assembly rules for fish life histories. Fish and Fisheries, 14(2): 213-224.

FAO. (2014). Socio-Economic Analysis of Egyptian Fisheries: Options for Improvement. GCP/INT/041/ EC-GREITA/TD-19. 
Gayanilo, F.C.; Sparre, P. and D. Pauly. (1996). FAO-ICLARM Stock Assessment Tools (FISAT). User's Manual. (Computerized Information Series Fisheries No. (8). Food and Agriculture Organization of the United Nations, Rome, and Pages: 126.

Gulland, J.A. (1971). The Fish Resources of the Ocean. 1st End, Fishing News Books, London; 255pp.

González, A. F.; Rasero, M. and Guerra, A. (1992a). Illex coindetii and Todaropsis eblanae (Cephalopoda, Ommastrephidae): their present status in Galician fisheries. International Council for the Exploration of the Sea (CM Papers and Reports), 5: 1-14.

González, A. F.; Rasero, M. and Guerra, A. (1992 b). Evidence for a recent and sudden increase in the abundance of Illex coindetii (Cephalopoda: Ommastrephidae) off the Galician coast (NW Spain). In Abstr. 11th. Malacol. Congress, Siena (pp. 304-306).

González, A. F. (1994). Bioecologia de Illex coindetii ((Verany 1839 Cephalopoda, Ommastrephidae) de las aguas de Galicia. Thesis doctoral, 237pp.

González, A. F.; Castro, B. G. and Guerra, A. (1996). Age and growth of the shortfinned squid Illex coindetii in Galician waters (NW Spain) based on statolith analysis. ICES Journal of Marine Science, 53(5): 802-810.

Guerra, A. (1992). Mollusca, Cephalopoda. In Fauna Ibérica Vol. 1. Ed. by M. A. Ramos et al., Museo Nacional de Ciencias Naturales. CSIC, Madrid, 327 pp.

Hernández-García, V. and Castro, J. J. (1998). Morphological variability in Illex coindetii (Cephalopoda: Ommastrephidae) along the north-west coast of Africa. Journal of the Marine Biological Association of the United Kingdom, 78(4): 1259-1268.

Jereb, P. and Ragonese, S. (1995). An outline of the biology of the squid Illex coindetii in the Sicilian Channel (Central Mediterranean). Journal of the Marine Biological Association of the United Kingdom, 75(2): 373-390.

Jones, R. and Van Zalinge, N. P. (1981). Estimates of mortality rate and population size for shrimp in Kuwait waters. Kuwait Bull. Mar. Sci, 2: 273-288.

Katagan, T.; Salman, A. and Benli, H. A. (1993). The cephalopod fauna of the Sea of Marmara. Israel journal of zoology, 39(3): 255-261.

King, M. (1995). Fisheries Biology, Assessment and Management. Fishing New Books, Oxford, England, $341 \mathrm{pp}$

Le-Cern, E. D. (1951). The length-weight relationship and seasonal cycle in gonad weight and condition in perch Perca fluviatilis. J. Anim. Ecol., 20 (2): 201-219.

Mangold-Wirz, K. (1963). Biologie des cephalopodes bentiques et nectoniques de la Mer Catalan. Vie et milieu, 13, 1-285.

Martin, P. (1993). Population dynamics of the exploited cephalopod species of the Catalan Sea (NW Mediterranean). Sci. Mar., 57: 153-159.

Nigmatullin, C. M. and Vovk A. N. (1972). Contribution to the biology of short finned squid Illex coindetii Vérany off Angola coasts. Trudy Atlant NIRO, 42: 162-166.

Pauly, D. (1983). Some simple methods for the assessment of tropical fish stocks (No. 234). Food \& Agriculture Org.

Pierce, G. J. and Guerra, A. (1994). Stock assessment methods used for cephalopod fisheries.

Perdichizzi, A.; Pirrera, L.; Giordano, D.; Perdichizzi, F.; Busalacchi, B.; Profeta, A. and Rinelli, P. (2011). Distribution patterns and population structure of Illex 
coindetii (Cephalopoda: Ommastrephidae) in the Southern Tyrrhenian Sea: Historical series of 14 years trawl survey. Fisheries research, 109(2-3): 342-350 Ragonese, S. and Jereb, P. (1992). Length-weight relationships of Illex coindetii Verany, 1839 (Mollusca: Cephalopoda) in the Sicilian Channel. Oebalia. 18: 17 $-24$.

Riad, R. (1993). Studies on cephalopod molluscs of the Mediterranean waters of Alexandria (Doctoral dissertation, M. Sc., Thesis, Faculty of Science, Alexandria University.

Ricker, W. E. (1975). Computation and interpretation of biological statistics of fish populations. Bull. Fish. Res. Bd. Can., 191: 1-382.

Roper, C. F. and Mangold, K. (1998). Systematic and distributional relationships of Illex coindetii to the genus Illex (Cephalopoda; Ommastrephidae). FAO FISHERIES TECHNICAL PAPER, pp.13-26.

Roper, C. F. E.; Nigmatullin, C. and Jereb, P. (2010). Family ommastrephidae. Cephalopods of the world. An annotated and illustrated catalog of species known to date, 2: 269-347.

Salman, A. (2017). Fecundity and Spawning Strategy of Short fin Squid Illex coindetii (Oegopsida: Ommastrephidae), In the Eastern Mediterranean. Turkish Journal of Fisheries and Aquatic Sciences, 17(4): 843-851.

Sánchez, P. (1981). Características bioecológicas de Illex coindetii (Verany, 1837) en el mar Catalán. Ph.D. Thesis, University of Barcelona, 219 pp.

Sánchez, P. (1982). Regimen alimentario de Illex coindetii (Verany, 1837) en el mar Catalán. Investigación Pesquera, 46: 443-449.

Sanchez, P. (1990). Age and growth of Illex coindetii (Verany, 1837) from Western Mediterranean. In ICES, 1990 Shell. Symp (No. 41, pp. 13)

Sánchez, P. (1995). Age and growth of Illex coindetii. In ICES Marine Science Symposia (Vol. 199:. 441-444). Copenhagen, Denmark: International Council for the Exploration of the Sea, 1991.-

Sánchez, P.; Belcari, P. and Sartor, P. (1998). Composition and spatial distribution of cephalopods in two north-western Mediterranean areas. South African Journal of Marine Science, 20(1): 17-24.

Sánchez, P.; González, F.; Jereb, P.; Laptikhovski, V.; Mangold, K.; Nigmatullin, Ch. M. and Ragonese, S. (1998b). Illex coindetii in Squid Recruitment Dynamics: the Genus Illex as a Model, the Commercial Illex Species and Influences on Variability, pp. 54-76. Ed. by P. G. Rodhouse, E. G. Dawe, and R. K. O’Dor. FAO Fisheries Technical Paper, 376. 273 pp.

Sparre, P. and Venema, S. C. (1992). Introduction to tropical fish stock assessment (p. 376). Rome: FAO Fisheries Technical Paper.

Tursi, A. and D'Onghia, G. (1992). Cephalopods of the Ionian Sea (Mediterranean Sea). Oebalia, 18:25-43. 